\title{
PENGARUH KOMBINASI METODE ZILGREI DAN ENDORPHIN MASSAGE TERHADAP LAMA KALA I FASE AKTIF
}

\author{
Sagita Darma Sari, Erin Octaviany ${ }^{1}$ \\ Program Studi DIII Kebidanan STIKES Abdurahman Palembang. Jl. Suka Jaya No. 07 Kel. Suka Ramai KM. \\ 5,5 \\ Email : sagitadarmasari98@gmail.com, erinoctaviany31@gmail.com
}

\begin{abstract}
Abstrak
Metode zilgrei terdiri atas latihan pernafasan, gerakan maupun posisi yang dapat membuat otot panggul menjadi selaras dan persalinan dapat berjalan lancar Endorphin massage merupakan sebuah terapi sentuhan/ pijatan ringan yang diberikan pada wanita hamil saat menjelang persalinan. Hal ini dilakukan karena pijatan merangsang tubuh untuk melepaskan senyawa endorphin yang merupakan pereda rasa sakit dan dapat menciptakan perasaan nyaman. Apabila metode zilgrei dan endorphin massage dikombinasikan menjadi suatu metode yang menggabungkan gerakan, perubahan posisi, latihan pernapasan, dan pijatan ringan yang dipersiapkan sejak kala I persalinan diharapkan kerja otot-otot panggul yang saling berkaitan menjadi selaras sehingga mulut rahim tidak kaku, dan adanya potensi otot-otot rahim untuk mendorong janin menuju jalan lahir. Penelitian ini bertujuan untuk mengetahui bagaimana Pengaruh Kombinasi Metode Zilgrei dan Endorphin Massage Terhadap Lama Kala I Fase Aktif Pada Ibu Inpartu. Penelitian ini menggunakan metode quasi eksperiment dengan penelitian Postest Only With Control Group Design. Hasil peneletian didapatkan Hasil uji $T$-Test secara komputerisasi didapatkan nilai P Value $0.003<\alpha(0,05)$ berarti Ho ditolak dan Ha diterima, hal ini menunjukkan bahwa ada pengaruh yang bermakna antara kombinasi metode zilgrei dan endorphin massage terhadap lama kala I fase aktif pada ibu inpartu primigravida di BPM Choirul Mala dan BPM Fauziah Hatta. Jumlah rata-rata lama kala I fase aktif pada ibu bersalin pada kelompok perlakuan yaitu 183 menit (3 jam 3 menit). Jumlah rata-rata lama kala I fase aktif pada ibu bersalin pada kelompok kontrol yaitu 255.70 menit (4 jam 15 menit).
\end{abstract}

Kata Kunci : Lama Kala I, Endorphin Massage, Metode Zilgrei.

\begin{abstract}
Zilgrei method consists of breathing practice, and movement and position practice which can make pelvic muscles work togedher so that maternity process can run well. Endorphin massage means a light touch/massage therapy which is given to pregnant woman prior to her maternity. This is given in order to stimulate the body to release the endorphin hormone which is a pain relief and is able to give comfortable feeling. If we combine zilgrei and endorphin massage method, we can combine movement, change the position, do breathing practice and give light massage which is prepared to face the first stage of labor and it is hoped that the work of pelvic muscles which are connected to one other can work together so that the uterus will not become stiff, and these muscles will be potential to push the baby's head toward the mother's pelvis. The objective of this study is to find out the influence of combining zilgrei and endorphin massage method on the lenght of active $1^{\text {st }}$ stage of labor among birth mothers. This study applied quasi-experimental method using posttest only with control group design. Based on this study using T-Test, it was found out that $\rho$ value $0.003<\alpha(0.05)$. it means that Ho was rejected and Ha was accepted. This showed that there was a significant influence between combining zilgrei and endorphin massage method and lenght of active firs stage of labor among birth mothers at Choirul Mala and Fauziah Hatta Independent Midwifery Practice. The average number of the active $1^{\text {st }}$ stage of labor lenght among birth mothers who belonged to treatment group was 183 minutes ( 3 hours 3 minutes). While the average number of the active $1^{\text {st }}$ stage of labor lenght among birth mothers who belonged to controlled group was 255.70 minutes (4 hours 15 minutes).
\end{abstract}

Keywords $\quad$ : The $1^{\text {st }}$ Stage of Labor, Endorphin Massage, Zilgrei Method. 


\section{PENDAHULUAN}

Salah satu faktor penyebab partus lama adalah rasa tidak nyaman dan nyeri yang dirasakan wanita seiring dengan kemajuan persalinan. Rasa nyeri dapat menimbulkan penurunan kontraksi uterus, sehingga meningkatkan angka kejadian SC, perdarahan post partum. Oleh karena itu, dalam dunia kedokteran terutama bidang anestesiologi telah mengembangkan berbagai macam pengobatan untuk mengurangi rasa sakit dan ketakutan selama proses persalinan. Sebenarnya, upaya menghilangkan rasa sakit dapat dilakukan secara farmakologi maupun nonfarmakologi.

Kala I adalah kala pembukaan yang berlangsung antara pembukaan satu sampai pembukaan lengkap. Lama kala I untuk primigravida berlangsung 12 jam sedangkan multigravida 8 jam (Manuaba, 2010). Kala I dibagi menjadi 2 fase yaitu fase laten dan fase aktif, kala I fase aktif dimulai dari pembukaan 4 sampai $10 \mathrm{~cm}$. Normalnya sesuai partograf, fase ini membutuhkan waktu \pm 6 jam. Oleh karena itu, fase aktif persalinan dikatakan memanjang jika lamanya melebihi 6 jam. Sebenarnya banyak faktor yang mempengaruhi kemajuan persalinan, namun kebanyakan primigravida merespon nyeri dengan rasa takut dan cemas yang dapat meningkatkan sekresi ketokolamin (epinefrin dan noreprinefin) yang menghambat pembukaan serviks kala I fase aktif persalinan (Yuliatun, 2008). Metode zilgrei terdiri atas latihan pernafasan, gerakan maupun posisi yang dapat membuat otot panggul menjadi selaras dan persalinan dapat berjalan lancar (Kuswandi, 2011). Salah satu cara penatalaksanaan nonfarmakologis lainnya adalah endorphin massage. Endorphin massage merupakan sebuah terapi sentuhan/pijatan ringan pada lengan, leher, bahu, punggung serta paha yang diberikan pada wanita hamil saat menjelang persalinan. Penelitian yang dilakukan oleh Suprapti mengenai metode Zilgrei yang diberikan pada ibu inpartu berpengaruh pada durasi kala II dan metode ini dapat dipergunakan untuk mempercepat kala II. Mengacu pada penelitian tersebut dengan metode Zilgrei kerja otot-otot panggul menjadi selaras sehingga tahapantahapan pembukaan menjadi lancar (Suprapti, 2006). Sedangkan Penelitian Insaffita (2007) dengan judul "Pengaruh Massage Punggung Terhadap Nyeri Primigravida Kala I Persalinan Fisiologis (Studi Kasus Di RSAB Gajayana Malang)" mendukung rasa nyeri dapat dikurangi dengan massage. Berdasarkan latar belakang tersebut, maka peneliti tertarik mengadakan penelitian tentang "Pengaruh Kombinasi Metode Zilgrei dan Endorphin Massage Terhadap Lamanya Kala I Fase Aktif Pada Ibu Inpartu".

\section{METODE PENELITIAN}

Jenis penelitian ini menggunakan desain penelitian Quasi-Eksperimental dengan menggunakan rancangan penelitian Postest Only With Control Group Design. Penelitian ini dilakukan pada bulan Mei dan Juni Tahun 2018 di BPM Hj. Fauziah Hatta dan BPM Choirul Mala Palembang. Populasi pada penelitian ini adalah seluruh ibu bersalin primigravida yang memasuki kala I Fase aktif dan kemudian ibu bersalin yang memenuhi kriteria akan masuk sebagai subjek penelitian. Jumlah sampel yang digunakan sebanyak 20 orang dan akan dibagi menjadi kelompok perlakuan (kombinasi metode zilgrei dan endorphin massage) dan kelompok kontrol (hanya metode zilgrei).

Sebelum melakukan penelitian, peneliti melakukan informed Consent kepada responden kemudian menentukan sampel sesuai dengan kriteria inklusi yang telah dibuat, pada saat pelaksanaan, peneliti menentukan kelompok yang diberi perlakuan dan kontrol secara bergantian, 
masing - masing kelompok diberikan perlakuan metode zilgrei selama 15 menit dan diulang selama 7-8 kali dan endorphin massage selama 15 menit dan di ulang setiap jam, sedangkan untuk kelompok Kontrol hanya diberikan metode zilgrei selama 15 menit dan diulang selama 7-8 kali, kemudian dilakukan observasi dan mencatat lama kala I fase aktif menggunakan lembar Check List dan partograf, setelah seluruh data terkumpul kemudian dilakukan entri data dan direkapitulasi, kemudian di analisis menggunakan uji statistik sehingga diketahui perbedaan lama kala I fase aktif pada setiap kelompok dan diketahui ratarata lama kala I fase aktif pada setiap kelompok. Analisis data penelitian ini menggunakan uji T-Test

\section{HASIL PENELITIAN DAN PEMBAHASAN}

Tabel 1. Distribusi Frekuensi berdasarkan pemberian metode zilgrei dan endorphin massage

\begin{tabular}{cccc}
\hline $\mathrm{N}$ & $\begin{array}{c}\text { Kombinasi metode } \\
\text { z } \\
\text { zilgrei dan } \\
\text { endorphin }\end{array}$ & Frekuensi & Presentase \\
& massage & & \\
& Perlakuan & 10 & $50 \%$ \\
\hline 1 & Kontrol & 10 & $50 \%$ \\
\hline
\end{tabular}

Berdasarkan tabel 1 diketahui bahwa dari 20 responden ibu bersalin yang diberikan kombinasi metode zilgrei dan endorphin massage sebanyak 10 responden $(50 \%)$ dan yang hanya diberikan metode zilgrei sebanyak 10 responden (50\%).

Tabel 2. Distribusi Frekuensi lama kala I fase aktif pada ibu inpartu

\begin{tabular}{cccc}
\hline $\begin{array}{c}\mathrm{N} \\
\mathrm{o}\end{array}$ & $\begin{array}{c}\text { Lama Kala I } \\
\text { Fase Aktif }\end{array}$ & Frekuensi & Presentasi \\
\hline 1 & $\leq 360$ menit & 20 & $100 \%$ \\
2 & $>360$ menit & 0 & $0 \%$ \\
\hline
\end{tabular}

Berdasarkan tabel 2 diketahui hasil peneletian didapatkan lama kala I fase aktif pada ibu bersalin $\leq 360$ menit sebanyak 20 responden dengan presentase $(100 \%)$.

Tabel 3. Pengaruh kombinasi metode zilgrei dan endorphin massage terhadap lama kala I fase aktif pada ibu inpartu.

\begin{tabular}{ccc}
\hline Kelompok & Mean & $\rho$ value \\
\hline Perlakuan & 183 menit & 0,003 \\
Kontrol & 255,7 menit & \\
\hline
\end{tabular}

Berdasarkan tabel 3 maka dapat dilihat dari hasil uji statistik $P$ Value $\alpha$ $0,003<0,05$ yang berarti ada perbedaan yang bermakna antara kelompok perlakuan (diberi kombinasi metode zilgrei dan endorphin massage) dibandingkan dengan kelompok kontrol (hanya diberikan metode zilgrei) dengan lama kala I fase aktif di BPM Choirul mala dan BPM Fauziah Hatta pada ibu inpartu. Dari tabel 3 diketahui lama rata - rata kala I fase aktif pada kelompok perlakuan sebesar 183 menit, lebih cepat dibandingkan kelompok kontrol sebesar 255,7 menit.

Berdasarkan hasil peneletian didapatkan lama kala I fase aktif pada ibu inpartu $\leq 360$ menit yaitu 20 responden dengan presentase (100\%). Pada kelompok perlakuan rata-rata jumlah lama kala I fase aktif pada ibu inpartu yaitu dengan durasi waktu 183 menit (3 jam 3 menit) lebih cepat di bandingkan pada kelompok kontrol ratarata lama kala I fase aktif yaitu 255.70 menit (4 jam 15 menit) pada ibu inpartu. Dari hasil tersebut di dapatkan kedua kelompok baik kelompok perlakuan maupun kelompok kontrol, kedua kelompok tersebut memiliki waktu rata-rata lama kala I fase aktif < 360 menit, hal ini dikarenakan kedua kelompok sama-sama diberikan perlakuan, hanya saja pada kelompok perlakuan diberikan kombinasi 
metode zilgrei dan endorphin massage sedangkan pada kelompok kontrol hanya diberikan metode zilgrei. Sehingga pada kelompok perlakuan (kombinasi metode zilgrei dan endorphin massage) lama kala I fase aktif nya lebih cepat dari pada kelompok kontrol (hanya metode zilgrei).

Berdasarkan penelitian yang dilakukan oleh peneliti di BPM Choirul Mala Husin dan BPM Fauziah Hatta tahun 2018 yang memenuhi kriteria inklusi penelitian, metode zilgrei dan endorphin massage menunjukkan bahwa kedua metode ini sama-sama memberikan hasil yang positif terhadap kemajuan persalinan kala I fase aktif pada ibu bersalin dan tidak menimbulkan gangguan pada janin. Hal tersebut sama dengan hasil yang di dapatkan oleh peneliti, sehingga dapat disimpulkan bahwa ibu bersalin yang mendapatkan perlakuan kombinasi metode zilgrei dan endorphin massage merasa lebih tenang, rileks dan nyaman dalam menghadapi proses persalinannya dan lama kala I fase aktif lebih singkat yaitu $<6$ jam.

Melalui metode zilgrei kerja otot-otot panggul yang saling berkaitan menjadi selaras sehingga mulut rahim tidak kaku, dan adanya potensi otot-otot rahim untuk mendorong janin menuju jalan lahir. Endorphin massage merangsang tubuh untuk melepaskan senyawa endorphin yang merupakan pereda rasa sakit dan dapat menciptakan rasa nyaman sehingga mempercepat kerja syaraf parasimpatis untuk menyampaikan perintah ke otak bagian belakang sehingga oksitosin disekresikan. Dengan meningkatnya sekresi hormon oksitosin maka meningkatkan frekuensi dan amplitudo kontraksi pada otot polos uterus sehingga mempersingkat kala I (Aprillia, 2011).

Hasil penelitian yang sama dilakukan oleh Endang, Nurasih dan Rizki (2013), tentang Pengaruh Kombinasi Metode Zilgrei dan Endorphin Massage Pada Ibu Inpartu Primigravida Terhadap
Lamanya Kala I, didapatkan nilai $\mathrm{P}$ value (0.001) lebih kecil dibandingkan dengan nilai ( $\alpha$ 0.05), sehingga Ho ditolak dengan rata - rata lama kala I fase aktif adalah 213 menit. Lama kala I fase aktif tercepat adalah 58 menit. Dar hasil estimasi interval disimpulkan bahwa 95\% diyakini bahwa rata - rata lama kala I fase aktif pada ibu inpartu primigravida adalah diantara 178,12 sampai dengan 248,59 menit. Hal ini menunjukkan terdapat pengaruh antara pemberian metode zilgrei dan endorphin massage pada ibu inpartu primigravida terhadap intensitas nyeri persalinan kala I fase aktif. Hasil dari penelitian Endang, dkk tersebut sama dengan hasil penelitian yang dilakukan oleh peneliti bahwa pada tindakan untuk membuat ibu menjadi merasa tenang, nyaman dan rileks serta menghasilkan hormon endorphin yang dapat memacu kerja syaraf parasimpatis untuk menyampaikan perintah ke otak bagian belakang sehingga oksitosin disekresikan dapat mempersingkat lama kala I fase aktif pada ibu inpartu.

\section{KESIMPULAN}

1. Hasil uji T-Test secara komputerisasi didapatkan nilai $P$ Value $0.003<\alpha$ $(0,05)$, hal ini menunjukkan bahwa ada pengaruh yang bermakna antara kombinasi metode zilgrei dan endorphin massage lama kala I fase aktif pada ibu inpartu di BPM Choirul Mala dan BPM Fauziah Hatta Palembang Tahun 2018.

2. Jumlah rata-rata lama kala I fase aktif pada ibu bersalin pada kelompok perlakuan yaitu 183 menit (3 jam 3 menit).

3. Jumlah rata-rata lama kala I fase aktif pada ibu bersalin pada kelompok kontrol yaitu 255.70 menit (4 jam 15 menit).

\section{SARAN}


Saran bagi peneliti selanjutnya untuk dapat menambah jumlah sampel penelitian untuk mendapatkan hasil yang baik lagi.

\section{UCAPAN TERIMA KASIH}

Peneliti mengucapkan terimakasih kepada responden yang telah bersedia untuk dijadikan subjek penelitian, serta ke dua BPM yang mengizinkan melakukan penelitian dan membantu dalam proses penelitian, tak lupa pula bagi peneliti ucapkan terimakasih kepada yayasan abdurahman yang memberikan support bagi peneliti.

\section{DAFTAR PUSTAKA}

1. Aprillia. 2011. Siapa Bilang Melahirkan Itu Sakit. Yogyakarta : CV. Andi Offset.

2. Endang, Nurasih dan Rizki. 2013. Pengaruh Kombinasi Metode Zilgrei dan Endorphin Massage Pada Ibu Inpartu Primigravida Terhadap Lamanya Kala I. Jurnal CARE, Vol. 2, No.2. 2014.

3. Kuswandi. 2011. Kehamilan dan Persalinan dengan Hipnobrithing. Jakarta : PT. Bhuana Ilmu Populer Kelompok Gramedia.

4. Insaffita. 2007. Pengaruh Massage Punggung Terhadap Nyeri Primigravida Kala I Persalinan Fisiologis. Thesis. Universitas Muhammadiyah Malang.

5. Manuaba. 2010. Ilmu Kebidanan, Penyakit Kandungan dan KB untuk Pendidikan Bidan. Jakarta : EGC.

6. Suprapti. 2006. Pengaruh Metode Zilgrei Terhadap Durasi Persalinan Kala II pada Ibu Inpartu.KTI. Poltekes Malang.

7. Yuliatun. 2008. Penanganan Nyeri Persalinan Dengan Metode Nonfarmakologi. Malang : Bayumedia Publishing. 